\title{
Research in ESP teaching and learning in French higher education: developing the construct of ESP didactics
}

La recherche sur l'enseignement-apprentissage de l'anglais de spécialité (ASP)

en France : pour une didactique de l'ASP

\section{Cédric Sarré and Shona Whyte}

\section{CpenEdition}

\section{Journals}

\section{Electronic version}

URL: http://journals.openedition.org/asp/4834

DOI: $10.4000 / a s p .4834$

ISSN: 2108-6354

\section{Publisher}

Groupe d'étude et de recherche en anglais de spécialité

\section{Printed version}

Date of publication: 9 March 2016

Number of pages: 139-164

ISSN: 1246-8185

\section{Electronic reference}

Cédric Sarré and Shona Whyte, « Research in ESP teaching and learning in French higher education: developing the construct of ESP didactics », ASp [Online], 69 | 2016, Online since 01 March 2017, connection on 02 November 2020. URL : http://journals.openedition.org/asp/4834 ; DOI : https:// doi.org/10.4000/asp.4834

This text was automatically generated on 2 November 2020

Tous droits réservés 


\title{
Research in ESP teaching and learning in French higher education: developing the construct of ESP didactics
}

\author{
La recherche sur l'enseignement-apprentissage de l'anglais de spécialité (ASP) \\ en France : pour une didactique de l'ASP
}

Cédric Sarré and Shona Whyte

\section{Introduction}

1 As the influential applied linguist and language assessment specialist Dan Douglas has pointed out, "the issue of defining and refining the concept of specific purpose language teaching is an ongoing and current task for practitioners" (2010: 11). This question also has repercussions for research in languages for specific purposes (LSPs) which this paper addresses via the following interrelated questions:

1. What are the key concepts and constructs necessary to the discussion of research in this area and what light is shed on this question by French perspectives on English for Specific Purposes (ESP) in higher education?

2. Is there a need for a theoretical research framework which is specific to the field of teaching and learning ESP?

3. How might research into a provisional framework for ESP didactics inform both practical pedagogical decision-making as well as contribute to more theoretical research in ESP teaching and learning in French higher education (and elsewhere)?

2 The paper begins by examining essential concepts and constructs, then provides background on research in ESP teaching and learning, followed by an overview of recent work in French higher education to identify common themes. The final section 
discusses a construct called ESP didactics and offers perspectives for future work in this area.

\section{Theory and practice in (language) teaching and learning}

3 The risk of terminological confusion in LSP teaching is high, since it includes a number of different fields of research, including (applied) linguistics, modern language studies, foreign language teaching and learning, and (language) education, and also involves researchers in different countries. As Bailly (2014: 15) notes:

As in other specializations, as didacticians we should not limit ourselves to our own school of thought or the classifications and categories we have become familiar with through our training and the institutional environment we operate in. We should instead widen our perspective through close and balanced analysis of the solutions offered by our colleagues from outside France.

With this in mind, the paper begins with an overview of key terms. Indeed, such are the differences between the scope and meaning of the French and English pairs didactique/ didactics, pédagogie/pedagogy and even linguistique appliquée/applied linguistics, that it is worth looking further afield and into the past in order to define and delimit current understanding of key concepts and constructs in the field of research in second/foreign language teaching and learning.

\subsection{Didactics and pedagogy}

LSP research in France stands at the intersection of European and Anglo-American research traditions. The terms didactics and pedagogy are widely used in many mainland European countries (France, Finland, Germany, Poland, Portugal, Spain, Switzerland), while in the English-speaking world, only pedagogy is commonly used in education research and the terms language learning and teaching, second language acquisition and learning, second/foreign/modern language education and second/foreign language methodology are often preferred (Kramsch 2000). This section compares the use of didactics and pedagogy in the long-established and influential German and Finnish traditions, in French approaches, and in Anglo-American research.

Harjanne and Tella claim that understanding teaching, the main object of didactics, has recently been complicated by terminological differences, creating what they call a "dilemma of didactics" (2007: 198). From an early definition which dates back to 1965, didactics in continental Europe has been loosely defined as "the science and study of teaching and learning" (ibid.: 203), with a strong theoretical orientation in keeping with the German tradition (Kansanen 2004). Pedagogy, on the other hand, is often defined in more practical, pragmatic terms: the "science of teaching embodying both curriculum and methodology" (Simon 1981, cited in Hamilton 1999: 138). However, Hamilton (1999) charts terminological slippage in the use of the terms pedagogy, syllabus, curriculum didactics, and method over centuries of educational thought and research in Europe. Since recent years have seen renewed interest in these key concepts, the time seems ripe to revisit current usage.

7 The Finnish concept of didactics is defined as (1) a science whose target is teaching, studying (i.e., what students do), and learning, and (2) a practice-based doctrine aimed 
at meeting prescribed learning objectives via teaching and studying (Tella 2002, cited in Harjanne \& Tella 2007). Finnish didactics has both a descriptive dimension, deriving from research on teaching, and a more prescriptive or normative dimension, concerning teaching instructions and curricula (Harjanne \& Tella 2007: 201). In other words, "the descriptive side of didactics is characteristic of a research approach and the normative side represents the practical viewpoint, with its arguments and justifications behind the educational decisions" (Kansanen \& Meri 1999: 107), suggesting an overlap between normative didactics and pedagogy. This is also the case for language didactics in France, which is defined in opposition to more immediate, concrete and practical pedagogical concerns in Bailly's seminal definition (1997: 10):

The modern, relatively recent interpretation of the term didactics refers a minima to an effort at distanciation, or in a fuller sense to the actual activity of theorising. Schematically in all cases, the observer or researcher abstracts him or herself from the immediate pedagogical context to analyse all the components of the object of teaching, the goals pursued in the pedagogical act, the strategies used by the teacher, the transformations of competences and behaviours which this teaching induces in the pupil and therefore the strategies used by the pupil to appropriate this object during learning activities. ${ }^{2}$

8 Language didactics is clearly considered as a distancing and theorising process during which the researcher takes a step back from the immediate teaching context. Language didactics is praxeology, that is to say an attempt to theorise pedagogical practices (Tardieu 2014: 85) or "an instrument to describe, analyse and reflect on the various dimensions of pedagogical reality, which helps us to better understand teaching practices" (Harjanne \& Tella 2007: 204). Like the Finnish term, the French construct is two-dimensional (Bailly 1997): a more descriptive dimension, termed didactique des chercheurs, corresponds to the theorising process previously mentioned, and a more normative dimension, called didactique institutionnelle, is formalised in national curricula and instructions and thus overlaps to a certain extent with the term "pedagogy."

9 If we now turn to the continental European notion of pedagogy, similar terminological problems arise (Harjanne \& Tella 2007: 199). Karsanen (1999) argues that while didactics and pedagogy can be considered as "parallel concepts", pedagogy generally concerns curricula, involves decision-making about teaching, and thus content, context, actors and objectives. Its main focus is teaching and education, as in the German tradition. Similarly, the French construct of pedagogy refers to an applied component of didactics, where the emphasis is clearly on teaching practices (Bailly 1997: 19). Put simply, didactics is knowledge-oriented, a science which aims to understand how teaching leads to learning, whereas pedagogy is practice-oriented, concerned more with applied aspects of language teaching. However, the problematic nature of the concepts lies not in the European understanding of the terms, but rather in Anglo-American usage.

\subsection{Didactics, pedagogy and second language acquisition}

10 In the English-speaking world, didactics is a concept with some pejorative overtones, often associated with lower-order, technical issues related to curriculum and teaching methods (Harjanne \& Tella 2007), and less connected to research (Kansanen 2009: 29). It is thus very uncommon for researchers publishing in English to use the term. 
Pedagogy, on the other hand (or sometimes even pedagogics), has been more widely accepted since the 1970s, though without a single, unambiguous meaning. Hamilton notes that "recent Anglo-American usage of 'pedagogy' mirrors the mainland European use of 'didactic" (1999: 135). If this is the case, we are merely confronted with a terminological difference: the Anglo-American concept of pedagogy corresponds to the continental European concept of didactics. It turns out, however, that Hamilton's claim seems to be particularly relevant to the 1970 s and 1980 s, a time when didactics in the German tradition "resurfaced in the English-speaking world as pedagogic analysis" (Hamilton 1999: 146). More recent use of the term in the English-speaking world of applied linguistics is quite different.

In the field of second or foreign language education, ${ }^{3}$ the term pedagogy is consistently used in relation to applications of language acquisition research and practical issues faced by practitioners (Gass 1995; Ellis 1997). With the maturation of the theoretical discipline of second language acquisition (SLA) in the late 1980s, researchers wanted to distinguish theoretical concerns from practical issues of teaching and learning languages. Gass shows how a "need for an emerging discipline (SLA) to show its strength, vitality and value" meant that Anglo-American researchers set out to sever links between research and teaching, a connection viewed by some as "unhealthy" (1995: 5). From this period, Hamilton's (1999) neat overlap between the Anglo-American term pedagogy and continental European didactics lost much of its relevance to language learning and teaching research because acquisitional approaches to our field took precedence over general educational models. From the early 1990s, SLA dominated theoretical approaches to language teaching in the English-speaking world, leaving the term pedagogy to cover more practical concerns.

Today the relevance of SLA research to language teaching is a matter of widespread agreement, consonant with its roots in a desire to improve instruction (Ellis 1997: 69). Some researchers refer to "applying SLA" in teaching (idem), which seems very close to the French view of pedagogy as "applied didactics." So, how do didactics and SLA compare? Within the field of applied linguistics, defined as "the theory and practice of language acquisition and use" (Kramsch 2000: 317), SLA originally referred to language acquisition in immersive contexts with native speakers of a language (Tardieu 2014: 87). Today SLA comprises a number of different strands, including instructed SLA, which focuses on cognitive, linguistic, affective and social factors affecting the learning of a second/foreign language in an instructional environment or classroom, in opposition to naturalistic SLA (Spada 2014: 41). SLA has also been loosely defined as "the general field of learning a non-primary language" (Gass 1995: 3) and has gradually replaced educational psychology as the theoretical base for language teaching in the US (Kramsch 2000: 313). SLA draws from several fields of research - linguistics, psychology, sociology and educational sciences - just as French didactics draws on various related fields (ibid.).

In contrast, researchers in foreign language education focus on the schooling process and therefore address questions such as standardisation of teaching and testing practices, syllabus and curriculum design, programme administration and models of teacher preparation (Kramsch 2000: 315). Anglo-American foreign language education therefore seems very similar to the French concept of didactique institutionnelle as previously defined. Finally, foreign language methodology is considered "an important field of knowledge for practitioners" (Kramsch 2000: 316) since foreign language 
methodologists aim to develop the most effective ways of teaching foreign languages. This strand of knowledge can be explicitly or implicitly informed by theory, although foreign language methodology shows a clear orientation towards practice at the expense of theory. In this respect, it seems similar to some components of mainland European pedagogy and therefore could be part of pedagogy. The different definitions of the concepts discussed in this section are summarized in Table 1.

Table 1. Different interpretations of didactics and pedagogy (adapted from Harjanne \& Tella 2007: 201)

\begin{tabular}{|c|c|c|c|c|}
\hline & German & Finnish & French & Anglo-American \\
\hline Didactics & $\begin{array}{l}\text { Didaktik } \\
\text { Related to } \\
\text { theory }\end{array}$ & $\begin{array}{l}\text { opetusoppi: } \\
\text { study of } \\
\text { teaching } \\
\text { (normative) } \\
\text { opetustied: } \\
\text { science of } \\
\text { teaching } \\
\text { (descriptive); } \\
\text { emphasis on } \\
\text { teaching, } \\
\text { in addition to } \\
\text { education }\end{array}$ & $\begin{array}{l}\text { 1.Didactique institutionnelle } \\
\text { (normative) } \\
\text { 2. Didactique du chercheur } \\
\text { (descriptive); } \\
\text { Distancing and theorising } \\
\text { process; emphasis on analysis } \\
\text { of teaching objectives and } \\
\text { strategies with reference to } \\
\text { contributive sciences; study } \\
\text { of how teaching leads to } \\
\text { learning }\end{array}$ & $\begin{array}{l}\text { Generally, not used. } \\
\text { Near-equivalent } \\
\text { concepts include } \\
\text { foreign language } \\
\text { education } \\
\text { Instructed SLA; emphasis } \\
\text { on the theories of } \\
\text { acquisition seen as the } \\
\text { interaction between } \\
\text { learners and the } \\
\text { educational and societal } \\
\text { context }\end{array}$ \\
\hline Pedagogy & $\begin{array}{l}\text { Pädagogik } \\
\text { Education } \\
\text { and } \\
\text { Teaching }\end{array}$ & $\begin{array}{l}\text { kasvatustiede } \\
\text { (educational } \\
\text { sciences), } \\
\text { system(at)ic } \\
\text { study of } \\
\text { education and/ } \\
\text { or teaching; } \\
\text { emphasis on } \\
\text { education, } \\
\text { in addition to } \\
\text { teaching }\end{array}$ & $\begin{array}{l}\text { pédagogie } \\
\text { An applied component of } \\
\text { didactics; } \\
\text { Emphasis on teaching } \\
\text { practices }\end{array}$ & $\begin{array}{l}\text { No established meaning; } \\
\text { since the 1970s, more } \\
\text { generally accepted, } \\
\text { sometimes } \\
\text { "pedagogics"; } \\
\text { in the 1970s and 1980s, } \\
\text { close to the European } \\
\text { concept of didactics; } \\
\text { from the 1990s onwards, } \\
\text { an applied component of } \\
\text { SLA }\end{array}$ \\
\hline
\end{tabular}

14 After this discussion of different interpretations of theoretical and practical aspects of the teaching and learning of second/foreign languages in general, we now turn to LSP, taking the example of the French context.

\section{Language teaching and research in French Higher Education}

15 French higher education traditionally separates language specialists - students of a modern language taking language-specific courses in linguistics, literary and cultural studies - from non-specialists - students in disciplines other than languages who are 
offered ESP classes, often as course requirements. These courses are part of what is commonly known as LANSAD (LANgues pour Spécialistes d'Autres Disciplines). Specialist language courses are largely taught by instructors with academic training in the target language and culture, many of whom are also literary scholars, and a major professional goal for students is secondary school English teaching (as EFL, or Modern Foreign Language, MFL). The same is not true of LSP courses. In this section we offer an overview of English studies and LSP teaching in France, before comparing AngloAmerican and French ESP.

\subsection{Teaching English studies}

16 The French study of anglistics (l'anglistique) is historically divided into three strands, now four with the more recent inclusion of ESP (Whyte 2014: 21):

Tardieu (2008) identifies "three traditional fields in English studies: linguistics, literature, culture" to which list she adds, following Perrin, English for Specific Purposes. ${ }^{4}$

17 Tardieu (2008: 2) situates English language didactics as a separate, transversal subdiscipline, a position which she considers as both an asset and a challenge:

Didactics shares with translation the difficulty of not belonging to a single territory, and not being situated exclusively within only one of these fields. Didactic research thus sometimes loses readability or is seen as a nomadic discipline. However, shouldn't this characteristic also be viewed as an asset in the sense that didactics can belong to all of these fields, and even that of translation? ${ }^{5}$

18 In this view, language didactics is seen as an overarching dimension with interrelations with all the other main aspects of English studies. It is legitimate to take an interest in the teaching and learning of the literature of English-speaking countries, of their culture, and of linguistic aspects of the many forms English takes; teaching and learning to translate into and out of English are also worthy of attention. Tardieu argues that these fields need not be treated exclusively in terms of curricular content and teaching methods (i.e., what is denoted by pedagogy in the European tradition, described in section 2), but can also constitute research objects in their own right, as part of a broader didactics of English studies.

Tardieu goes on to suggest ways in which the field of didactics can carve out a research space within English studies, with the caveat that "it is necessary in this case to decide on an epistemological stance" (cited in Whyte 2014: 15).

Reflection on the epistemological status of a didactics of English studies in France led to the creation in 2011 of a new learned society in this area, ARDAA (Association pour la Recherche en Didactique de l'Anglais et en Acquisition). ARDAA brings together researchers in both specialist and LANSAD sectors of French higher education and therefore includes teacher educators, for whom language teacher education research is a teaching concern as well as a research interest. ARDAA is affiliated with the academic association the SAES (Société des Anglicistes de l'Enseignement Supérieur), which represents English studies in French higher education. The SAES has over twenty affiliate learned societies covering the four major fields of English studies as well as related subfields, including one for ESP. It is clear that didactics has therefore taken on increasing importance in French higher education in recent years. 


\subsection{Teaching ESP}

21 Turning now to ESP teaching, courses are generally intended to prepare students for non-teaching uses of the target language. As shown in several recent studies (Whyte 2011; Braud et al. 2015), the majority of ESP teachers in French higher education do not have disciplinary training and are not involved in research activities. However, the need for a research foundation for ESP teaching has been addressed at institutional level through the activities of academic and professional LSP organisations such as the vocational language teachers' association APLIUT (Association des Professeurs de Langues en IUT) and the higher education ESP research group GERAS (Groupe d'Étude et de Recherche en Anglais de Spécialité); both seek to bridge the gap between research and teaching in LSP (Trouillon 2010: 15). Although ESP research and teaching are often qualified as "innovative" (Mémet \& Petit 2001: 8; Hyland 2006: 35) with a more "international" scope than other areas of language education (Master 2005; Paltridge \& Starfield 2011), outsiders sometimes view them as "the less glamorous, low rent neighbourhoods of the academy" (Hyland 2006: 34).

APLIUT and GERAS teachers and researchers find common ground in the study of Anglais de spécialité (ASP). There are obvious similarities between ESP and ASP which can be explained by the fact that ASP originates in ESP (Mémet 2001). However, the French approach to the field diverges from ESP traditions in the English-speaking world, specifically as regards its learning/teaching dimension.

An early definition of ESP is offered in a seminal volume by Hutchinson and Waters (1987: 19) and runs as follows:

ESP must be seen as an approach not as a product. ESP is not a particular type of language or methodology, nor does it consist of a particular type of teaching material. Understood properly, it is an approach to language learning, which is based on learner need. The foundation of all ESP is the simple question: Why does this learner need to learn a foreign language?

Here priority is given to learner needs, and ESP is thus firmly grounded in language learning. A decade later, in another landmark publication by key authors in the field, Dudley-Evans and St John (1998: 4-5) offered a similar, more detailed characterisation of ESP:

1. Absolute characteristics:

ESP is designed to meet specific needs of the learners;

ESP makes use of the underlying methodology and activities of the disciplines it serves;

ESP is centred on the language (grammar, lexis, register), skills, discourse and genres appropriate to these activities.

2. Variable characteristics:

ESP may be related to or designed for specific disciplines;

ESP may use, in specific teaching situations, a different methodology from that of general English;

ESP is likely to be designed for adult learners, either at a tertiary level institution or in a professional work situation. It could, however, be used for learners at secondary school level;

ESP is generally designed for intermediate or advanced students. Most ESP courses assume basic knowledge of the language system, but it can be used with beginners.

Here all three absolute characteristics and three of the four variable characteristics are directly linked to teaching and learning. They read more like curricular guidelines than 
the theoretical definition of a construct. Therefore, there seems to be a shift in the definition of ESP from Hutchinson and Waters' (1987) focus on language learning to Dudley-Evans and St John's (1998) orientation towards language teaching. This change can be viewed as a shift from theoretical (SLA) to more practical concerns (language teaching methodologies), which were previously excluded by Hutchinson and Waters (1987).

Potential outlets for ESP research in the English-speaking world encompass both definitions. The aims and scope of the flagship journal of ESP, English for Specific Purposes, are quite explicit, including all aspects of ESP teaching and learning, from both theoretical and more practical viewpoints. While discourse and linguistic aspects of ESP are mentioned as potential areas of interest to journal readers, their relevance is judged only in relation to the teaching and learning of ESP rather than as topics of research in their own right.

In the French context, the territory of ASP is mapped somewhat differently. Following in the footsteps of pioneers such as Costa and Perrin who helped ASP achieve recognition in French academia in the 1970s and early 1980s (Baïssus 2008), Petit (2002: 2) offered the first definition of ASP to gain wide acceptance in France:

The branch of English language studies which concerns the language, discourse and culture of English-language professional communities and specialised social groups, as well as the teaching of this object. ${ }^{6}$

French ESP is considered as a subdiscipline of English studies (just as geometry is a subdiscipline of mathematics), that is, both a strand of knowledge and a subject to be taught. Petit's definition also lays emphasis on four elements: (1) English studies in general; (2) language viewed in its linguistic, discourse and cultural dimensions; (3) specialization, one example of which is professional specialization; and (4) teaching. Interestingly, there is no mention of learning here and no reference to the necessary interrelations between research in ESP and research in language didactics. However, others have since argued that ESP ought to take into account "our current knowledge of language learning and English language teaching in particular" (Bertin 2008: 5).

ASp, the major French journal in this area, adopts a much wider didactic perspective (or "didactic dimension") in its editorial policy than Petit (2002), referring not only to the teaching of ESP, but also to various theoretical frameworks that can be used, including, for example, those related to language learning theory, to the teaching of ESP in particular higher education courses, to ergonomics or even technology integration in ESP learning and teaching. This view of ESP is therefore all-encompassing, unlike Petit's definition whose didactic dimension was completely unspecified. This analysis of different definitions of ESP is summarized in Table 2.

Table 2. A summary of ESP definitions

\begin{tabular}{|l|l|l|}
\hline $\begin{array}{l}\text { Hutchinson } \\
\text { Waters (1987) }\end{array}$ & \&udley-Evans \& St John (1998) & $\begin{array}{l}\text { Petit } \\
\mathbf{( 2 0 0 2 )}\end{array}$ \\
\hline $\begin{array}{l}\text { ESP as an approach to } \\
\text { language learning }\end{array}$ & $\begin{array}{l}\text { ESP in terms of core characteristics } \\
\text { and optional features of language } \\
\text { teaching }\end{array}$ & $\begin{array}{l}\text { ESP as a subdiscipline of English } \\
\text { studies }\end{array}$ \\
\hline
\end{tabular}




\begin{tabular}{|c|c|c|}
\hline $\begin{array}{l}\text { Emphasis on learner } \\
\text { needs }\end{array}$ & $\begin{array}{l}\text { Emphasis on } \\
\text { learner needs } \\
\text { methodological choices in relation to } \\
\text { professional contexts } \\
\text { linguistic aspects of specialised } \\
\text { language }\end{array}$ & $\begin{array}{l}\text { Emphasis on } \\
\text { the varied dimensions of } \\
\text { specialised language: linguistic, } \\
\text { discursive, cultural } \\
\text { the teaching of this subdiscipline }\end{array}$ \\
\hline
\end{tabular}

It is worth noting that the French equivalent to the term LSP didactics has been widely used in the French literature, suggesting the existence of a well-established construct referred to by three different expressions in French. "La didactique des langues de spécialité" (LSP didactics) seems to be the most common (Spillner 1992; Bertin 1994; Sturge-Moore 1997; Celotti \& Musacchio 2004; Dechamps 2004; Isani 2006, 2010; Rossi 2007), followed by "la didactique des langues spécialisées" (Mourlhon-Dallies 2006; Messaoudi 2013); French employs both "langue de spécialité" and "langue spécialisée" to refer to the single concept of "specific purposes" in English. A third expression, "la didactique des langues et cultures spécialisées" (Isani 2011), places greater emphasis on the cultural dimension. Similarly, the term ESP didactics (la didactique de l'anglais de spécialité) has also been used extensively in French doctoral theses and research papers (Brouat 1994, 1997; Claisse 1995; Thily 1996; Rézeau 2001; Zumbihl 2004; Isani 2006, 2014; Coquilhat 2008).

Does this mean that LSP didactics and, more specifically, ESP didactics are obvious or well-established concepts? Given that some of these authors seem to only refer to pedagogical considerations (Brouat 1994; Celotti \& Musacchio 2004; Dechamps 2004) and that these concepts are never defined by the researchers who use them, one can only infer that they are considered self-explanatory. Following Bachelard (1938), however, concepts which are not well defined but instead considered obvious may in fact be preconceived misconceptions. In this view, they should be regarded as epistemological obstacles which need to be overcome in any attempt to contribute to scientific knowledge. An epistemological break is therefore necessary in order to define the construct of ESP didactics by making preconceptions explicit and clarifying notions and concepts.

\subsection{The didactic strand of ESP research}

These key terminological distinctions lead us to define the following position on research in ESP learning and teaching in France. This strand of ESP research is didactic by nature and clearly falls within the scope of didactique des chercheurs in so far as it

(1) is a distancing and theorising process which seeks to analyse the way ESP teaching leads to learning,

(2) draws on several contributive sciences,

(3) takes a broader perspective than SLA, covering elements of both SLA and foreign language education.

This strand of ESP research is not restricted to pedagogy as defined in this section; Petit's (2002) definition of ASP must therefore be revised to align with current research as the branch of English language studies which concerns the language, discourse and 
culture of English-language professional communities and specialised social groups, as well as the learning and teaching of this object from a didactic perspective. ${ }^{7}$ This revision forms the focus of section 4 below.

Does this mean that the didactic strand of ESP research should be considered as a subdiscipline of language didactics? Just as Petit (2002) considers ESP to be a subdiscipline of English, and Douglas (2010) views ESP testing as a special case of language testing, should didactic research in ESP in turn constitute a subdiscipline of general English didactics? If so, what we could then call ESP didactics could be defined in relation to general didactics, language didactics and English didactics on "a continuum of specificity" (Douglas 2010: 9). The construct of language didactics is already widely recognized as a subject-didactic component of general didactics (Harjanne \& Tella 2007), and English didactics (didactique de l'anglais), a special case of language didactics, is also an accepted research field in French universities and elsewhere. Now the question arises as to whether ESP learning and teaching situations are specific enough to justify a separate scientific construct. Is ESP learning and teaching sufficiently distinct from general English language learning and teaching? What purpose might be served by a specific construct for ESP didactics? A need for further clarification in this area has been at the origin of the creation of a Special Interest Group (SIG) within the higher education ESP research organisation GERAS with the explicit objective of exploring the specificity of research in ESP teaching and learning. Elements of this reflection are presented in section 4 .

\section{The DidASP SIG: teaching contexts and research interests}

Recent years have seen intensive discussion among ESP researchers in French higher education, particularly within GERAS, on the importance of reinforcing the didactic dimension of research within the French school of ESP (Taillefer 2013; Whyte 2013). As noted in section 3, and unlike general English studies, didactics was from the early days one of four key dimensions of ESP - along with linguistics, culture and technology. Since then, however, it has somewhat fallen from favour. Petit's (2002) definition laid the foundations of the French school of ESP research and, as we have seen, clearly gave priority to the language of specific purposes rather than the teaching or learning of this language. Focus on linguistic and cultural aspects of ESP no doubt reflected efforts to gain scholarly respectability on a par with literary and cultural research in mainstream English studies; French ESP researchers sought to break away from the applied dimension of didactic research (i.e., its links to teaching) in a quest for academic recognition. This concern for the scholarly status of ESP research thus reflects both external factors, in relation to more traditional strands of research in English studies, and internal pressures, from competing strands of ESP research itself.

Against this background, the creation of a Special Interest Group (SIG) devoted to the study of the epistemological status of a didactic strand of ESP research in France seemed an effective way of promoting a research-based approach to the study of ESP teaching and learning in France. Traditionally, GERAS SIGs have focused on particular varieties of ESP (English for law, medicine, or economics), and provided opportunities for their members to share course materials, advise on language policy in specific contexts, and engage in collaborative projects such as dictionaries and corpora. The 
ESP didactics SIG (DidASP for Didactique et anglais de spécialité) is somewhat different, focusing on cross-disciplinary concerns and questioning teaching and learning practices to identify characteristics specific to these learning and teaching situations and which can inform the epistemological foundations of language didactics. Our aim is therefore to examine the transversal nature of ESP learning and teaching situations and isolate both absolute and variable characteristics of these situations (cf. DudleyEvans \& St John 1998).

\subsection{Overview of teaching and research contexts}

Table 3 provides a summary of recent research in teaching and learning ESP in French higher education, including information on methodological frameworks and references.

Table 3. Overview of DiDASP SIG contributions

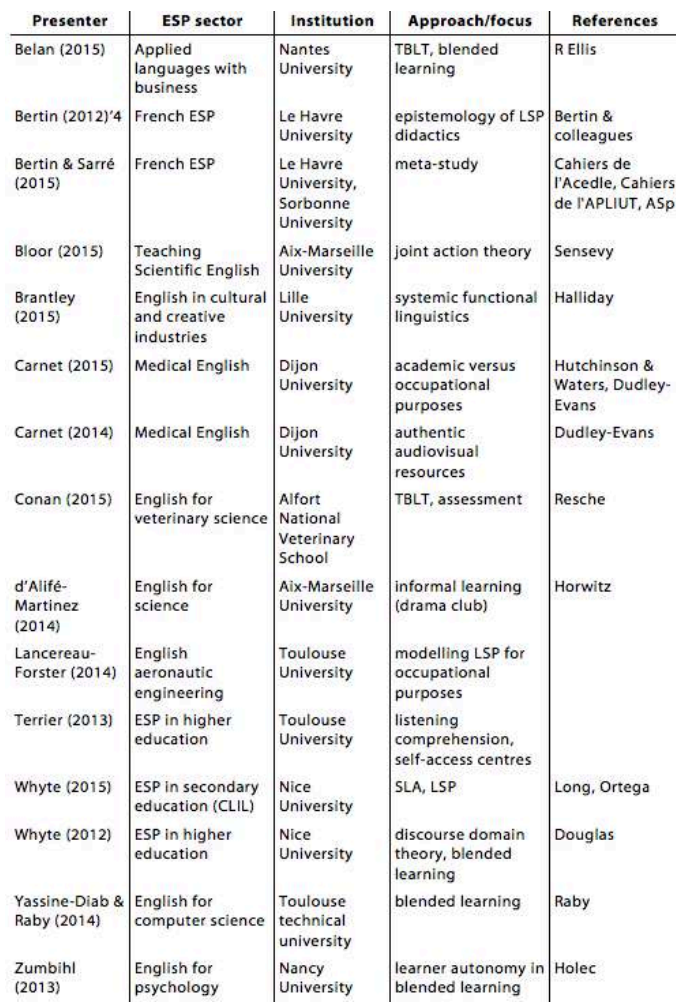

41 Table 3 thus shows 16 talks by 15 presenters in 12 different French higher education institutions in contexts varying widely in terms of fields of study, teaching and learning goals, and research interests. ${ }^{8}$ Concerning the different fields of ESP involved, half of our presentations (8/16) involved science and engineering, either quite specific subjects such as medicine (Carnet 2014, 2015), veterinary science (Conan 2015) and aeronautical engineering (Lancereau-Forster 2014), or more general science degrees (Bloor 2015; Colin 2015; d'Alifé-Martinez 2014). Five others concerned arts or humanities, including psychology (Zumbihl 2013) and applied languages with business (Langues Etrangères Appliquées - Belan 2015), while three talks involved the whole ESP sector (Bertin 2012; Bertin \& Sarré 2015; Terrier 2013). As noted, current GERAS Special Interest Groups include English for science, medicine, law and business/economics; only the first two are represented in our corpus. Most presentations concerned 
university ESP courses, mainly mainstream rather than elite institutions (grandes écoles), with one technical university (IUT). This orientation reflects the French institutional structure whereby instructors whose positions involve teaching and research are appointed to universities, while teaching-only positions are common in other higher education settings.

With respect to ESP teaching and learning objectives, the group's presentations covered a range of different goals and contexts. While some talks clearly favoured occupational ESP goals (Lancereau-Forster 2014), others identified tensions between these and more academic ESP requirements (Carnet 2015; Conan 2015). For many, perhaps especially in arts and humanities, actual learner needs and objectives were often ill-defined (Belan 2015; Brantley 2015; Whyte 2012). In terms of approaches to teaching, several presenters referred to task-based language teaching (TBLT) and to blended courses combining face-to-face sessions, often in self-access centres, with online activities (Belan 2015; Whyte 2012; Yassine-Diab \& Raby 2014; Zumbihl 2013). The role of content-specialist instructors and coordination with language instructors also arose (Bloor 2015; Yassine-Diab \& Raby 2014). Talks spanned a continuum from formal to informal learning, including questions of standards and assessment at one end of the scale (Carnet 2014; Colin 2015; Conan 2015), and affective variables such as motivation and anxiety at the other (d'Alifé-Martinez 2014). Finally, issues of authenticity and intercultural communication arose, with tensions between the need to evaluate ESP knowledge and competence on one hand, and the goal of preparing students for study abroad or future professional contexts on the other (Brantley 2015; Carnet 2015; Conan 2015).

Regarding the orientations to research shown by different group members, studies drew on a wide range of theoretical frameworks, from Anglo-American interactionalcognitive approaches (Belan 2015; Whyte 2015) and narrower ESP perspectives (Carnet 2015; Colin 2015; Whyte 2012) through French didactic traditions (Bertin 2012; Bloor 2015; Yassine-Diab \& Raby 2014; Zumbihl 2013) to broader questions of learner affect (d'Alifé-Martinez 2014) and intercultural concerns (Conan 2015; Zumbihl 2013). Some questioned the interface between general and LANSAD language education (Terrier 2013; Whyte 2012) while Bertin \& Sarré (2015) reported on an ambitious meta-study of (ESP) language didactic research in France as part of ongoing efforts to map the field. In the next section, a number of common themes emerging from discussion of these presentations are listed.

\subsection{Common themes and directions}

The varied teaching and research contexts for ESP in French higher education described in 4.1 can be summarized in five key dimensions which constitute a basis for collaborative enterprise and reflection:

Learner needs analysis: what is it that students need to learn? What knowledge and skills do they already possess? What particular strengths and weaknesses need to be accommodated? Concerning learner autonomy and informal language learning, to what extent is it possible or desirable for learners to develop language competence outside institutional structures?

Domain or content area for ESP: how is the specific purpose defined and delimited? What descriptions are available (corpora, reference works)? What kind of cultural and 
intercultural awareness is relevant and what intersections with English as a Lingua Franca (ELF) seem to be appropriate?

Professional context: what are the habits and conventions of the profession associated with the domain? What are the key activities, competences and expertise of central members of communities of practice ( $\mathrm{COP}$ ) associated with a given domain? How are they developed, and how can teachers best support this process?

Language acquisition: what kind of language competences are expected? Are linguistic, communicative, strategic, and discourse competences equally important? What are the expectations of stakeholders, including learners, teachers, educators, professional colleagues and employers? How are language competences generally assessed and evaluated?

Language teaching: what institutional constraints operate on opportunities for language learning and teaching? Who are the teachers available, what kind of background and training do they have? What teaching resources have been developed, what authentic materials are available? Is there a need to develop pedagogical resources? Are particular approaches better suited to ESP teaching than others (e.g., task or project-based teaching and learning)? Are bridges to other educational sectors (e.g., secondary, vocational) relevant?

We now ask how these key questions fit with the previous discussion of French ESP as compared to ESP in the English-speaking world, and what other concepts are necessary to the development of French ESP didactics.

\section{Towards a didactics of ESP}

The original questions posed at the outset of this paper concerned (1) the relevance of French perspectives on key concepts in research in ESP teaching and learning, (2) the need for a theoretical ESP didactic framework, and (3) the potential value of such a framework.

\subsection{French perspectives on key concepts in research in ESP teaching and learning}

Regarding the first question, it appears that there is some justification to this call for clarification in the area of research in ESP teaching and learning, at least in the current French higher education context. While this may appear unsurprising to readers given the usual conventions of academic writing, since authors generally orient their research questions towards an intended outcome, the claim warrants examination for the second author of this paper at least. Indeed, Whyte (2013: 24-25) argued in answer to the question of "a need for a new approach to language learning and teaching that is tailored to English for Specific Purposes" that

we already have theories of language acquisition and use, as well as language teaching, which can inform effective ESP teaching and learning. English is one language among many, and all are learned via universal processes; similarly, the specific purposes of our courses are all amenable to task-based approaches.

53 Two arguments from the foregoing sections of the paper do, however, serve to justify this new research framework. The first is terminological. We have seen that the terms 
pedagogy and didactics are used in overlapping, contrasting and frequently poorly defined ways by researchers in different disciplines, contexts, and geographical areas. We have identified differences in the use of the same terms in general education over time and space (Hamilton 1999; Kansanen 2009), in French approaches to English studies (Bailly 1997; Tardieu 2008) and in French as opposed to Anglo-American approaches to each (Gass 1995; Bailly 1997, Kramsch 2000). Even within ESP, FrenchEnglish differences are apparent which date from the earliest formalisations of the domain in French higher education (Petit 2002). The second argument concerns the current renewal of interest in research in language teaching and learning in French higher education from an institutional point of view, as exemplified by both the new learned society ARDAA, focusing on theoretical aspects of the teaching and learning of English in French secondary and tertiary education, as well as by the debate leading to the new GERAS SIG on ESP didactics. Scholars are seeking fresh, research-oriented approaches to the foreign language classroom, particularly as regards ESP.

In some ways, different researchers are bound to define and map their own research territory according to their own contexts, interests and needs. Figure 1 offers one perspective on the overlapping research interests of the second author of this paper which places ESP didactics at the intersection of SLA, ESP and ELT research. Linking SLA and ESP is a particular theory of SLA concerning the role of specialised knowledge in second language development (Douglas 2004). An overlap between ESP and ELT is a shared interest in task-based language teaching and the connection between SLA and ELT involves methodological principles based on research (Doughty \& Long 2003).

Figure 1. Intersections of SLA, ESP and ELT (Whyte 2014: 19)

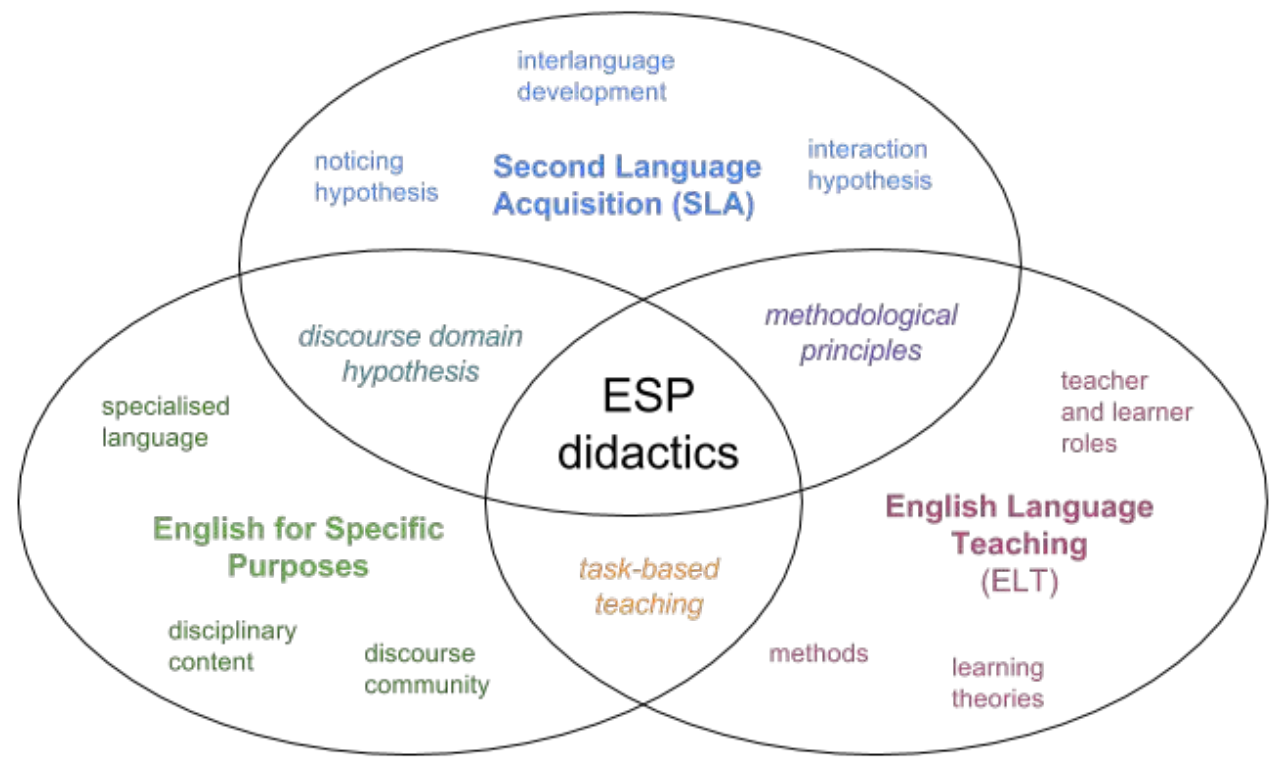

It is easy to understand how approaches to the same construct from different directions might involve different areas of research to create different intersections. Within the field of English studies, for example, ARDAA researchers will define English didactics with reference to other areas of English studies, of which ESP is only one. Similarly with respect to ESP testing, Douglas (2010) sets ESP testing against other forms of language testing rather than other aspects of English linguistics or literature. 
In each case, however, researchers are prompted by specific real-world problems, looking for appropriate theoretical frameworks to account for different dimensions of complex objects and thus inform both practical decisions about pedagogy and teacher education, and ongoing language teaching and learning research, that is, didactics.

We believe this epistemological endeavour to be worthwhile, and given the importance of ESP - the "English as a lingua franca of the learning and working world" (Master 2005: 112) - that ESP didactics also has a practical function. To take the first key area identified in section 4, for example, the issue of learner needs is quite specific to ESP. For one thing, in many institutional contexts such as compulsory secondary education, for example, teachers are simply expected to meet predetermined curricular objectives and thus never address specific learner needs. Second, certain ESP contexts do not require general language competence but only restricted skills (e.g., reading comprehension in the case of a technician required to consult manuals [Trouillon 2010]), meaning that ESP learners also differ from general EFL learners along this dimension.

\subsection{Need for a research framework specific to ESP teaching and learning}

Regarding the second question about the need for a research framework specific to the teaching and learning of ESP, our main hypothesis was that if there were a sufficient number of features specific to ESP learning and teaching, then research on these learning and teaching situations would warrant a specific framework which could be formalised in a unified construct, that of ESP didactics. This construct needs to be related to the specific contexts outlined in section 3, as well as anchored in theory as shown in sections 2 and 3 of the paper. As we have seen, the main objective of the DidASP SIG has been to identify what makes ESP learning and teaching specific in the French context.

From the themes and questions discussed in section 4.2, a list of specific features of ESP learning and teaching can be classified as absolute or variable characteristics of French ESP didactics:

Absolute characteristics:

- Interaction between language and content knowledge: content and/or methodologies are derived from specific disciplines or occupations, the specialist domain (Douglas 2010);

- Goal-directedness: the objectives of ESP learning and teaching are specific and directed towards particular skills and knowledge (language and culture) of a given discipline or occupation, learner ability to complete tasks as "real-world activities";

- Needs analysis: the objectives of ESP learning and teaching are determined through careful needs analysis;

- Institutional constraints:

- Student background and level: highly heterogeneous groups at university (slightly less so for more selective pathways - e.g. engineering schools)

- ESP as a course requirement, which impacts student motivation

- Group size

- Contact time (very restricted) 
Variable characteristics:

- Primacy of task completion (over language accuracy): performance vs. accuracy, ESP as an example of English as a Lingua Franca (ELF);

- Primacy of specific language skills development;

- Use of authentic materials;

- Use of specific methods: tasks (TBLT), project-based learning, CLIL;

- Use of language certification, specific ESP testing, development of ESP certification exams;

- Basic teacher training in ESP (often limited or absent) for non-research professionals.

As these specific features of ESP learning and teaching are part of a whole ESP learning and teaching situation, they may be represented as a dynamic system in Figure 2, adapted from Bertin's didactic ergonomics model (Bertin \& Gravé 2010; Bertin 2012; Bertin \& Sarré 2015).

Figure 2. The ESP teaching and learning situation

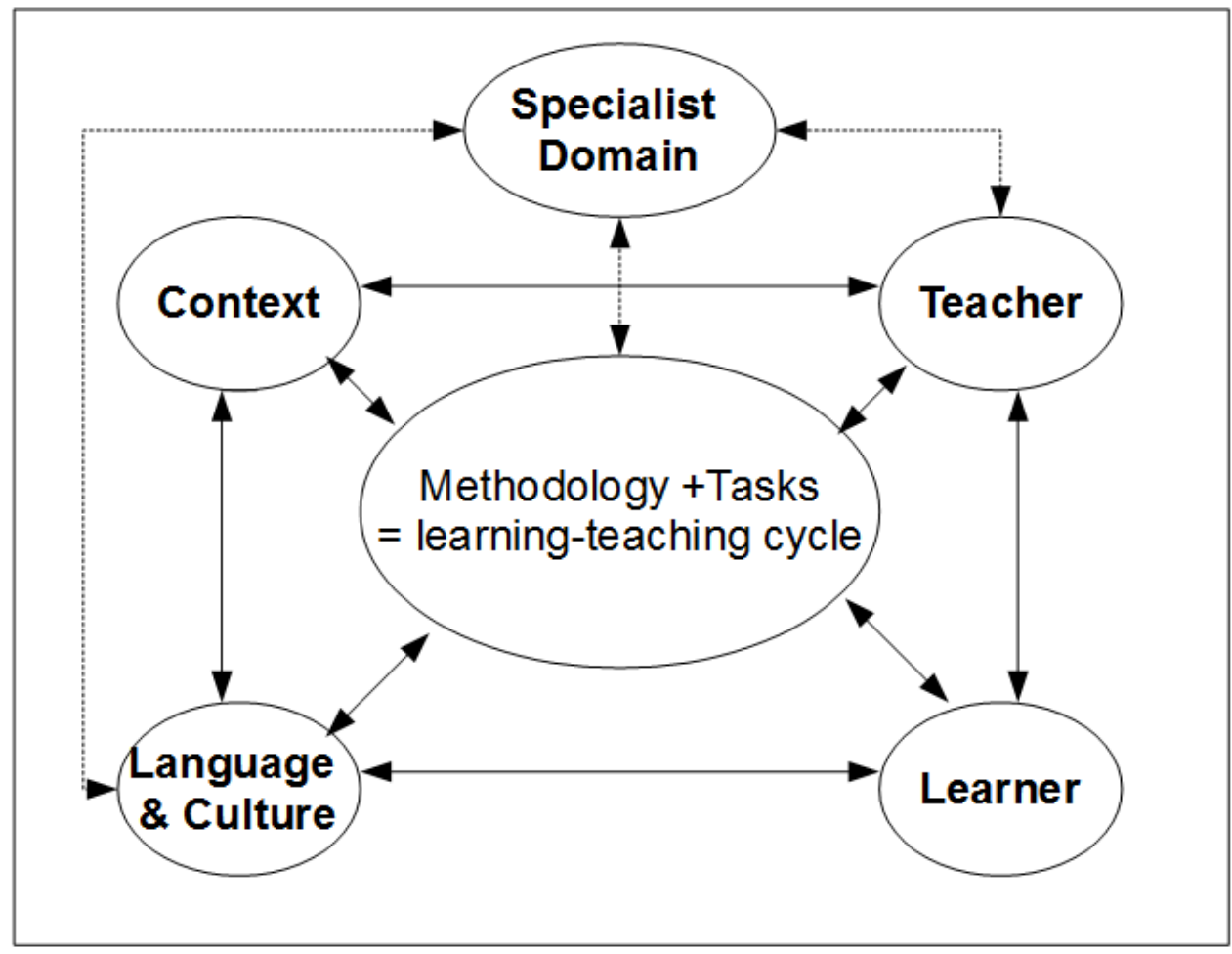

Figure 2 shows that the specialist domain, although not a pole in the actual system, directly or indirectly affects all five poles of the ESP learning and teaching situation (context, language and culture, learner, teacher and learning-teaching cycle). For example, we can describe the direct influences at work (represented as dotted lines with arrowheads) at three levels. First, the specialist domain influences the language and culture to be taught/learnt, as different domains call for the study and knowledge of different terminologies, genres, discourses and cultures. Then, the specialist domain and the various methodologies derived from it are claimed to impact learning, as factors such as learner motivation, for example, greatly differ in ESP courses (Mémet 2003). Finally, the specialist domain also influences the knowledge required of teachers, and, as a result, the type of training they should receive. In addition, the specialist domain also indirectly influences some of the poles in the system: for instance, the 
teacher performs a needs analysis relevant to the specialist domain and then designs programmes and course descriptions which, in turn, become part of the context as new curricula.

63 ESP learning and teaching thus appears to be much more specific than general English learning and teaching. In a similar manner, reflection on ESP learning and teaching processes will be strongly affected by the specialist domain, which should also influence research in ESP learning and teaching.

\subsection{Contribution of the ESP didactics construct}

Finally, regarding an ESP didactics framework to inform further research, we hope this paper can contribute to reflection and debate in this area. At the pedagogical level, our work in the DidASP SIG to date has perhaps inevitably highlighted a number of practical concerns regarding teacher education for ESP contexts. Braud et al. (2015) call for the inclusion of an ESP option in pre-service teacher preparation (as an option in secondary teacher entrance exams, for example); vocational teacher preparation is another obvious area for attention. Regarding didactics, on the other hand, our overview in section 3 highlights a number of intersections in DidASP members' interests. It thus provides impetus to future research initiatives, perhaps in the form of research collaborations replicating ESP studies conducted elsewhere, and involving the building of our own learner corpora. There is still a pressing need for "empirical research demonstrating the efficacy of ESP" as opposed to the "war stories and romances" often exchanged (Master 2005: 111).

To conclude, there appears to be a real need among French faculty involved in ESP teaching/learning research for common theoretical ground. Although we are not yet ready to offer a fully-fledged definition of the ESP didactics construct, we are now in a position to say that ESP teaching and learning is specific enough to justify the development of a research framework in its own right. The definition of the ESP didactics construct, which we have begun to delimit in this paper, seems a worthwhile and attainable objective. Indeed, if we go back to Bachelard (1938) and the different steps in the construction of scientific knowledge, we have effected an epistemological break (step 1) and, although we have clarified the meaning of some key concepts in this paper, we are still in the process of constructing ESP didactics (step 2). It seems quite possible to propose clear, consensual definitions of both didactics and ESP which take into account differences due to language and research traditions, and much of this paper has been taken up with this preliminary work. We have shown how French ESP takes a slightly wider didactic perspective than mainstream Anglo-American ESP research. We have outlined a definition of didactics which is accepted in France and much of continental Europe; with respect to the corresponding research area in the English-speaking tradition, we have also suggested that didactics covers a wider area than SLA, covering elements of both SLA and foreign language education. We therefore believe this epistemological endeavour to be an important undertaking, and that there are good reasons why ESP didactics should establish itself as a discipline in its own right in the French context and beyond. 


\section{BIBLIOGRAPHY}

BACHELARD, Gaston. 1938. La formation de l'esprit scientifique. Paris: Librairie philosophique J. Vrin.

BAILly, Danièle. 1997. Didactique de l'anglais, vol. 1 \& 2. Paris: Nathan Pédagogie.

BAILly, Danièle. 2014. "Préface”. In TARDIEU, C., Notions-clés pour la didactique de l'anglais. Paris:

Presses Sorbonne Nouvelle.

BAÏSSUS, Jean-Marie. 2008. “Le préGERAS”. ASp, numéro spécial - Les trente ans du GERAS, 7.

BERTIN, Jean-Claude. 1994. "L'enseignant, le professionnel et l'apprenant : confrontation des cultures et choix des matériaux pédagogiques". ASp 5-6, 69-78.

BERTIN, Jean-Claude. 2008. "Le mot du Président”. ASp, numéro spécial - Les trente ans du GERAS, 2-6.

BERTIN, Jean-Claude \& Patrick GRAVÉ. 2010. “In favor of a model of didactic ergonomics". In BERTIN

J.-C., P. GRAVÉ \& J.-P. NARCY-COMBES, Second-language Distance Learning and Teaching: Theoretical perspectives and didactic ergonomics. Hershey: IGI Global, 1-36.

BRAUD, Valérie, Philippe MILlot, Cédric SARRÉ \& Séverine WOZNIAK. 2015. "Pour une formation de tous les anglicistes à la langue de spécialité”. Les Langues Modernes 3/2015, 67-76.

BROUAT, Thérèse. 1994. “Qu'y a-t-il de commun entre Napoléon et un ordinateur portable ? La culture comme vaste réservoir à analogies". ASp 5-6, 79-88.

BROUAT, Thérèse. 1997. "Le dire et l'induire : l'argumentaire dans les publicités informatiques anglo-saxonnes ; contribution à la didactique de l'anglais des spécialités scientifiques et techniques". Unpublished doctoral thesis, université de Chambéry.

CELOTTI Nadine \& Maria Teresa MUSACCHIO. 2004. "Un regard diachronique en didactique des langues de spécialité”. Ela. Études de linguistique appliquée 3/2004 (nº135), 263-270 $<$ www.cairn.info/revue-ela-2004-3-page-263.htm>.

CLAISSE, Dominique. 1995. "De divergences en convergence : Value, ou le triomphe du consommateur à l'américaine”. ASp 7-10, 263-275.

COQUILHAT, Jean-Christophe. 2008. "Mise à distance d'un enseignement de l'anglais de l'informatique : expérimentations et analyses de quelques aspects méta-didactiques et cognitifs de l'acquisition en anglais de spécialité". Unpublished doctoral thesis, université Bordeaux 2.

DECHAMPS, Christina. 2004. "Enseignement/apprentissage des collocations d'une langue de spécialité à un public allophone : l'exemple de la langue juridique". Ela. Études de linguistique appliquée 3/2004 ( $\left.{ }^{\circ} 135\right)$, 361-370 <www.cairn.info/revue-ela-2004-3-page-361.htm>.

DOUGHTY, Catherine J. \& Michael LoNG. 2003. "Optimal psycholinguistic environments for distance foreign language learning." Language Learning \& Technology 7, 50-80.

DOUGLAS, Dan. 2004. "Discourse domains: The cognitive context of speaking." In BOXER D. \& A. COHEN (Eds.), Studying Speaking to Inform Second Language Learning. Clevedon, UK: Multilingual Matters, 25-47.

DOUGLAS, Dan. 2010. “This won't hurt a bit: Assessing English for nursing”. Taiwan International ESP Journal 2/2, 1-16. 
DUDLEY-EVANS, Tony \& Maggie Jo ST JOHN. 1998. Developments in English for Specific Purposes. Cambridge: Cambridge University Press.

ELLIS, Rod. 1997. “SLA and second language pedagogy". SSLA 20, 69-92.

English for Specific Purposes. Journal aims and scope. <http://www.journals.elsevier.com/englishfor-specific-purposes/>.

GASS, Susan. 1995. "Learning and teaching: The necessary intersection”. In ECKMAN, F. et al. (Eds.), Second Language Acquisition Theory and Pedagogy. Mahwah, NJ: Erlbaum, 3-20.

Hamilton, D. (1999). The pedagogic paradox (or why no didactics in England?). Pedagogy, Culture and Society, 7(1), 135-152.

HARJANNE, Pirjo \& Seppo TELLA. 2007. "Foreign language didactics, foreign language teaching and transdisciplinary affordances". Foreign languages and multicultural perspectives in the European context, 197-225.

HUTCHINSON, Tom \& Alan WATERS. 1987. English for Specific Purposes. Cambridge: Cambridge University Press.

HYLAND, Ken. 2006. “The 'other' English: Thoughts on EAP and academic writing”. The European English Messenger 15/2, 34-38.

ISANI, Shaeda. 2006. "Langue, lecture et littérature populaire : FASP et didactique des langues de spécialité". Cahiers de l'APLIUT XXV/3, 92-106.

ISANI, Shaeda. 2010. "Dynamique spéculaire de la fiction à substrat professionnel et didactique des langues de spécialité". ASp 58, 105-123.

ISANI, Shaeda. 2011. "Developing professional cultural competence through the multi-layered cultural substrata of FASP: English for Legal Purposes and M. R. Hall's The Coroner". Cahiers de l'APLIUT XXX/2, 29-45.

ISANI, Shaeda. 2014. "Ethnography as a research-support discipline in ESP teaching, learning and research in the French academic context". ASp 66, 27-39.

KANSANEN, Pertti. 2004. "The role of general education in teacher education". Zeitschrift für Erziehungswissenschaft 7/2, 207-218.

KANSANEN, Pertti. 2009. "Subject-matter didactics as a central knowledge base for teachers, or should it be called pedagogical content knowledge?". Pedagogy, culture \& society 17/1, 29-39. KANSANEN, Pertti \& Matti MERI. 1999. "The didactic relation in the teaching-studying-learning process". Didaktik/Fachdidaktik as Science (-s) of the Teaching profession 2/1, 107-116.

KRAMSCH, Claire. 2000. "Second language acquisition, applied linguistics, and the teaching of foreign languages”. Modern Language Journal 84/3, 311-326.

MASTER, Peter. 2005. "Research in English for specific purposes". In HINKEL, E. (Ed.) Handbook of Research in Second Language Teaching and Learning. London/New York: Routledge, 99-116.

MÉMET, Monique. 2001. "Bref historique de l'enseignement et de la recherche en anglais de spécialité en France : de l'anglais pour non-spécialistes à l'anglistique du secteur LANSAD”. In MÉMET M. \& M. PETIT (Eds.) L'anglais de spécialité en France : Mélanges en l'honneur de Michel Perrin. Bordeaux: GERAS Éditeur, 309-319. 
MÉMET, Monique. 2003. “L’enseignement à contenu intégré augmente la motivation pour l'apprentissage de la langue : vrai ou faux ?" Étude portant sur des cours d'anglais de spécialité en médiation culturelle. ASp 39-40, 131-142.

MÉMET, Monique. 2013. “Historique de l'ASP”. ASp. <http://asp.revues.org/607>.

MÉMET, Monique \& Michel PETIT (Eds.). 2001. L'anglais de spécialité en France : Mélanges en l'honneur de Michel Perrin. Bordeaux: GERAS Éditeur.

MESSAOUDI, Leila. 2013. "Les technolectes savants et ordinaires dans le jeu des langues au Maroc". Langage et Société 2013/1, 143, 65-83.

MOURLHON-DALLIES, Florence. 2006. "Le français à visée professionnelle : enjeux et perspectives". Synergie Pays riverains de la Baltique 3, 89-96.

PALTRIDGE, Brian \& Sue STARFIELD. 2011. "Research in English for specific purposes". In HINKEL, E. (Ed.) Handbook of Research in Second Language Teaching and Learning. Volume 2. London/New York: Routledge, 196-121.

PETIT, Michel. 2002. “Éditorial”. ASp 35/36, 1-3.

RÉZEAU, Joseph. 2001. "Médiatisation et médiation pédagogique dans un environnement multimédia. Le cas de l'apprentissage de l'anglais de l'histoire de l'art à l'université". Unpublished doctoral thesis, Université Bordeaux 2.

RossI, Micaela. 2007. "Didactique des langues de spécialité au niveau universitaire : l'apport de la terminologie. Description de deux expériences didactiques”. Synergies Italie, 3, 46-56.

SPADA, Nina. 2014. "Instructed Second Language Acquisition Research and Its Relevance for L2 Teacher Education”. Education Matters 2/1, 41-54.

SPILLNER, Bernd. 1992. "Textes médicaux français et allemands : Contribution à une comparaison interlinguale et interculturelle". Langages 105, 42-65.

STURGE-MOORE, Olivier. 1997. "La mondialisation de l'économie : de nouveaux enjeux, de nouveaux contextes culturels". ASp 15-18, 325-338.

TAILLEFER, Gail. 2013. “CLIL in higher education: the (perfect?) crossroads of ESP and didactic reflection". ASp 63, 31-53.

TARDIEU, Claire. 2008. "Place de la didactique dans l'anglistique”. Journée d'étude SAES Caractéristiques et fonctions de la didactique de l'anglais, IUFM de Paris. <http:// storage.canalblog.com/83/81/603294/57987043.pdf>.

TARDIEU, Claire. 2014. Notions-clés pour la didactique de l'anglais. Paris: Presses Sorbonne Nouvelle. THILY, Hervé. 1996. "L'apport des nouvelles technologies d'information et de communication dans la didactique de l'anglais de spécialité. Sections de techniciens supérieurs (conception de produits industriels)". Unpublished doctoral thesis, Université de Chambéry.

TROUILLON, Jean-Louis. 2010. Approches de l'anglais de spécialité. Perpignan: Presses universitaires de Perpignan.

WHYTE, Shona. 2011. "Learning theory and technology in university foreign language education. The case of French universities". Arts and Humanities in Higher Education 10/2, 213-234.

WHYTE, Shona. 2012. “Quelle didactique pour l'anglais de spécialité?” DidASP SIG meeting, Paris, October. 
WHYTE, Shona. 2013. “Teaching ESP: A task-based framework for French graduate courses". ASp $63,5-30$.

WHYTE, Shona. 2014. “Contextes pour l'enseignement-apprentissage des langues : le domaine, la tâche et les technologies". Note de synthèse pour l'Habilitation à diriger des recherches.

WILLIAMS, Christopher. 2014. "The future of ESP studies: building on success, exploring new paths, avoiding pitfalls". ASp 66, 137-150.

ZUMBIHL, Hélène. 2004. “Cadre théorique et méthodologique d'une étude sur l'acquisition de la compétence de médiation culturelle en milieu universitaire". ASp 43-44,125-134.

\section{APPENDIXES}

\section{Appendix: List of talks in the DIDASP SIG}

BELAN, Sophie. 2015. “Approches de l'anglais de spécialité dans la filière LEA”. DidASP SIG meeting, Paris, October.

BERTIN, Jean-Claude. 2012. "Didactique et anglais de spécialité". DidASP SIG meeting, Paris, October.

BERTIN, Jean-Claude \& Cédric SARRÉ. 2015. "Didactique des langues et LSP : entre adaptation à un objet spécifique et émergence du concept original de didactique des LSP". Journée d'étude DidASP, CeLiSo et ESPE Paris. Paris, 10 April.

BLOOR, Tracy. 2015. "La théorie de l'action conjointe en didactique comme outil descriptif de la perspective actionnelle”. Journée d'étude DidASP, CeLiSo et ESPE Paris. Paris, 10 April.

BRANTLEY, Kate. 2015. "An approach to LSP classes based on functional linguistics". DidASP SIG meeting, Paris, October.

CARNET, Anaïs. 2014. “Utilisation de la série HOUSE, MD en anglais médical”. DidASP SIG meeting, Marseille, March.

CARNET, Anaïs. 2015. "Vers une didactique de l'anglais médical à visée professionnelle". Journée d'étude DidASP, CeLiSo et ESPE Paris. Paris, 10 April.

CoLIN, Catherine. 2015. "Les certifications en anglais de spécialité : révélatrices de dynamiques didactiques". DidASP SIG meeting, Paris, October.

CONAN, Muriel. 2015. "Enseigner l'anglais vétérinaire à Alfort : LSP, perspective actionnelle et certification". Journée d'étude DidASP, CeLiSo et ESPE Paris. Paris, 10 April.

D'ALIFÉ-MARTINEZ, Laurence. 2014. "Réduire les inhibitions par le biais d'un atelierthéâtre en LANSAD”. DidASP SIG meeting, Paris, 10 October.

LANCEREAU-FORSTER, Nicole. 2014. "Vers une didactique de l'anglais de spécialité à visée professionnelle". DidASP SIG meeting, Paris, October.

TERRIER, Linda. 2013. "De la linguistique à la didactique, de l'anglais général à l'anglais de spécialité - quelques réflexions sur la notion de didactique de l'anglais de spécialité à travers le cas de la compréhension de l'anglais oral". DidASP SIG meeting, October. 
WHYTE, Shona. 2012. “Quelle didactique pour l'anglais de spécialité?” DidASP SIG meeting, Paris, October.

WHYTE, Shona. 2015. "Quand tout le monde sera spécialiste : la place des langues dans l'enseignement secondaire". Journée d'étude DidASP, CeLiSo et ESPE Paris. Paris, 10 April.

YASSINE-DIAB, Nadia \& Françoise RABY. 2014. "SMILE, une déclinaison d'un dispositif EMILE”. DidASP SIG Meeting, Marseille, March. zUMBIHL, Hélène. 2013. “Anglais de spécialité et autonomisation de l'apprenant”. DidASP SIG meeting, October.

\section{NOTES}

1. Il nous est en effet nécessaire, en didactique comme dans d'autres champs de spécialisation, de ne pas nous en tenir à nos habitudes de pensée, aux classifications et catégories qui nous sont familières de par notre formation et notre cadre institutionnel de fonctionnement, et de nous décentrer en examinant de près et loyalement les solutions proposées par nos collègues d'ailleurs.

2. Le terme «Didactique", dans son acception moderne - relativement récente - renvoie, au moins, à une démarche de distanciation et, au plus, à une pleine activité de théorisation: schématiquement, il s'agit dans tous les cas, pour un observateur ou un expérimentateur, de s'abstraire de l'immédiateté pédagogique et d'analyser à travers toutes ses composantes l'objet d'enseignement, les buts poursuivis dans l'acte pédagogique, les stratégies utilisées par l'enseignement, les transformations de compétences et de conduites que cet enseignement induit chez l'élève et par conséquent les stratégies d'appropriation de l'objet déployées par cet élève lors de son activité d'apprentissage.

3. The terms 'foreign' and 'second' language are also used somewhat inconsistently in the literature: for some, second language is a superordinate term including all languages learned after the first language regardless of context. Others reserve the term for a language learned in a context where the target language is an ambient language, in opposition to a foreign language, learned in isolation from native speakers, as is the case for most instructed ESP in Europe.

4. Pour Tardieu (2008) subsistent «trois champs traditionnels de l'anglistique: linguistique, littérature, civilisation » auxquels il convient d'ajouter selon l'auteur et suivant Perrin, l'anglais de spécialité.

5. [L]a didactique partage avec la traduction cette difficulté à n'habiter qu'un territoire, à ne pouvoir se situer à l'intérieur d'un seul de ces champs de manière exclusive, d'où, parfois, son absence de lisibilité ou le nomadisme de ses travaux. Mais cette caractéristique n'est-elle pas aussi un atout au sens où la didactique peut se situer à l'intérieur de tous ces champs et même de celui de la traduction?

6. [L]a branche de l'anglistique qui traite de la langue, du discours et de la culture des communautés professionnelles et groupes sociaux spécialisés anglophones et de l'enseignement de cet objet.

7. La branche de l'anglistique qui traite de la langue, du discours et de la culture des communautés professionnelles et groupes sociaux spécialisés anglophones et de l'enseignementapprentissage de cet objet selon une entrée didactique.

8. See list of sixteen talks in the appendix. 


\section{ABSTRACTS}

This paper tackles the question of research on the teaching and learning of English for Specific Purposes (ESP) in France and presents the initial stages of work on the development of a theoretical framework which is specific to this field of research. It examines arguments for the development of a concept of ESP didactics and the framework underpinning research in the teaching and learning of ESP. It considers links between this concept and the didactics of languages and of English, on the one hand, and ESP research on the other. To this end, the paper begins with an analysis of different interpretations of key concepts in language teaching and learning, then provides an overview of language education in French higher education, with particular attention to ESP teaching and learning. Research in ESP teaching is then examined with reference to the new GERAS special interest group DidASP, in order to both highlight the range of contexts and approaches investigated, and identify common themes and issues.

Cet article aborde la question de la recherche sur l'enseignement-apprentissage de l'anglais de spécialité (ASP) en France et présente les premières étapes d'un travail sur le développement d'un cadrage théorique spécifique à ce champ de recherche. Nous nous interrogeons ainsi sur la pertinence du développement du concept de didactique de l'ASP, cadre théorique spécifique à la recherche sur l'enseignement-apprentissage de l'ASP, et sur ses liens avec la didactique des langues et de l'anglais, d'une part, et avec la recherche en ASP, d'autre part. Nous proposons une analyse des différentes acceptions des concepts clés relatifs à l'enseignement-apprentissage des langues, avant de dresser un panorama de l'enseignement-apprentissage des langues dans l'enseignement supérieur français, et de l'ASP en particulier. La recherche est ensuite abordée à travers l'analyse des travaux présentés au sein du Groupe de travail Didactique et ASP du GERAS, analyse qui nous permet de souligner la variété des contextes et des approches, et d'identifier un certain nombre de thématiques et de préoccupations communes.

\section{INDEX}

Mots-clés: acquisition des langues, anglais de spécialité, didactique, enseignementapprentissage des langues, épistémologie

Keywords: didactics, English for Specific Purposes, epistemology, ESP, language education, second language acquisition

\section{AUTHORS}

\section{CÉDRIC SARRÉ}

Cédric Sarré is a senior lecturer at Université Paris-Sorbonne, School of Education (ESPE), where he teaches English as a Foreign Language and English Language Learning and Teaching. He is a member of the CeLiSo (Centre de Linguistique en Sorbonne) research unit. His research focuses on language learning technologies (Computer-Assisted Language Learning and ComputerMediated Communication). His research interests include ESP didactics, ESP course development in online settings, the integration of technology in language learning and teaching, language proficiency testing and teacher education. He co-chairs the DidASP special interest group on ESP didactics within GERAS. cedric.sarre@paris-sorbonne.fr 


\section{SHONA WHYTE}

Shona Whyte is associate professor at Université Nice Sophia Antipolis where she teaches English as a foreign language, translation and second language acquisition and teaching. A member of the research unit Bases, Corpus, Language, she is responsible for the Masters in Teaching English at the ESPE Nice, and codirects special interest groups on language teacher education research within GERAS (GT DidASP) and EuroCALL (Teacher Education SIG). Recent EU projects are iTILT, on interactive whiteboards in language education, and iTILT 2, on interactive language teaching with a variety of technologies. Her research interests include computer-assisted language learning, particularly classroom interaction and teacher integration of technologies. Recent publications include Implementing and Researching Technological Innovation in Language Teaching (Palgrave Macmillan 2015) and the co-edited volume Teaching languages with technology: communicative approaches to interactive whiteboard use (Bloomsbury 2014). whyte@unice.fr 